\begin{tabular}{|c|c|}
\hline & $\begin{array}{l}\text { International Journal of Trend in Scientific } \\
\text { Research and Development (IJTSRD) }\end{array}$ \\
\hline 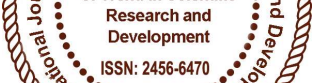 & International Open Access Journal \\
\hline 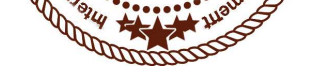 & ISSN No: 2456 - 6470 | www.ijtsrd.com | Volume - 2 | Issue - 2 \\
\hline
\end{tabular}

\title{
A Study on Awareness Level of Investors towards the Methodology of Credit Rating Agencies
}

\author{
Dr. Ekta Rokade \\ Lecturer, School of Economics, Devi Ahilya Vishwavidyalaya (DAVV), \\ Indore, Madhya Pradesh, India
}

\begin{abstract}
During late 1980s, a few financial institutions in India felt the need for establishing an entity which could take up the task of, and help in the assessment of risk associated with the investment in the backdrop of experience of Bond Rating Agencies in western countries. A bunch of financial institutions promoted an entity called Credit Rating Information Services of India Limited (CRISIL) in 1987. There are, at present, five Rating Agencies in India which offer services of Rating and assessment agency (i.e., ONICRA) is working in India. In this study, the researcher has tried to measure the perception of investors towards the rating of financial instruments for long term investment. For this study total 100 investors were selected from Indore Division.
\end{abstract}

\section{Introduction}

The increasing number of financial instruments and ever the expansion of financial markets provide both borrowers and investors with large number of funding and investing options. As the number of companies borrowing directly from the capital market increases and as the industrial environment becomes more and more competitive and demanding, it is difficult for investors to make a right choice among the multiplicity of instruments and fund raisers particularly where all the borrowers have a good name and reputation. Further, the growing number of cases of defaults and frauds in payment of interest and repayment of principal sum borrowed has increased the importance of credit rating.

Therefore, investors feel a growing need for an independent and credible agency which judges impartially, the credit quality of debt obligations of different companies and assist investors, individuals and institutions in making investment decisions (Singh, 1996). Thus, Credit Rating Agencies fulfil this need of investors as the main purpose of credit rating is to provide investors with comparable information on credit risk based on standard rating scales regardless of the specifics of the companies. The increasing role of capital and money markets consequent to disintermediation; Increased securitization of borrowing and lending consequent to disintermediation; Globalization of credit market; Continuing growth of information technology; Growth of confidence in the efficiency of the open market mechanism; Withdrawal of Government safety nets and the trend towards privatization (Arora, 2003).

Thus, in the changed scenario where corporate are increasingly dependent on public, the removal of restrictions on interest rates and stipulation of a mandatory credit rating of a number of instruments since 1991 by the government / SEBI, credit rating has emerged as a critical element in the functioning of Indian debt or financial markets. It is useful to safeguard the interest of investors by guiding them towards the right path. Credit rating is desirable and mandatory for certain instruments worldwide to caution the investors in advance about the strength and weaknesses of a fund raising company. 
Thus, the credit rating agencies evaluate the intrinsic worth of a company and assign ranks to the companies accordingly. These agencies have become important in view of the increasing number of companies going to the public for funds and also due to government stipulating that corporate bodies wanting to raise funds from the market should have their debt instrument rated. The main objective of these agencies is to restore the confidence in the capital market and to provide unbiased assessment of credit worthiness of the companies issuing debt instruments. Credit Rating Agencies are essentially corporations with specialized functions, namely, assessment of the likelihood of the timely payments by an issuer on a financial obligation (known as credit rating'). Thus, credit rating' is essentially the task of determining the strength and prospects of a security offered in the market and thereupon place it amongst a band having predetermined standards called grades ${ }^{6}$ (typically these grades are symbolically represented, viz. A, AA, AAA, etc.) (Jain and Sharma, 2008).

\section{Important Determinants of Credit Rating :-}

The ratings are so devised that they provide investors with a simple and easily understood indicator expressing the underlying credit quality and the risk associated with an instrument of debt (Rao et al., 1996). Each rating assigned to a security issue is a reflection of various factors. Rating does not based on a pre-determined mathematical formula that fixes the relevant variables as well as the weights attached to each of them. Rating agencies do a great amount of number chomping, but the final outcome also takes into account factors like quality of management, corporate strategy, economic outlook and international environment.

Effects of India's Demonetization as per Moody's Rating:-

Withdrawing all INR 500 \& 1000 notes by the Government of India affect all sectors of economy with banks the key beneficiary. In the longer term the measures in the near term will pressure GDP growth and revenues of Government of India. There is a need to boost the revenues and translate into higher Government capital expenditure and fiscal consolidation. Corporates are affected in terms of lower sales volume and cash flows with those directly exposed to retail sales. Moody's concluded that demonetization is beneficial for Indian Government and Banks Moody's remarked that in short period; definitely demonetization had disrupted economic activity resulting in temporarily weaker consumption and GDP growth.

\section{Rating Symbols :-}

Rating symbols are indicators of the opinion/assessment of credit rating agency regarding credit quality or grade of the debt obligations or instruments. The rating agencies have standardized rating nomenclatures for long-term ratings, short-term instruments, medium-term ratings, etc. The comparative analysis of the symbols used by various credit rating agencies is shown in Tables given below:

Table 1: Rating Symbols for Long Term Instruments

\begin{tabular}{|l|l|l|l|}
\hline CRISIL & ICRA & \multicolumn{1}{c|}{ CARE } & \multicolumn{1}{c|}{ Remarks } \\
\hline AAA & LAAA & CAREAAA & Highest Safety \\
\hline AA & LAA & CAREAA & High Safety \\
\hline A & LA & CAREA & Adequate Safety \\
\hline BBB & LBBB & CAREBBB & Moderate Safety \\
\hline BB & LBB & CAREBB & Inadequate Safety \\
\hline B & LB & CAREB & High Risk \\
\hline C & LC & CAREC & Substantial Risk \\
\hline D & LD & CARED & Default \\
\hline
\end{tabular}

From the table, it has been evident that all these three rating agencies use similar rating symbols for long term instruments. The long term instruments are divided into two groups; investment group and hypothetical group. The symbols from AAA to A denote the investment group ranges from the highest safety to adequate safety and the second one group is speculative means that symbols from $\mathrm{BBB}$ to $\mathrm{B}$ presents from moderate safety to high risk and the last two C \& D based on the speculations of market. Hence, for investment the first three ratings are safe and investors are in comfortable zone.

\section{Rationale of the Study:-}

Companies are turning towards the market for their short-term and long-term financial requirements instead of conventional method of looking at the banks and financial institutions. The investors cannot easily compute and compare the associated risk with an array of financial instruments available in the market. Assessment of associated risk, therefore, calls for a razor-sharp expertise. Hence, the assessment and evaluation of risk is carried on in India, as in other parts of the world, by a group of experts who possesses the specialized skills. Credit Rating occupies a significant place in the investment arena as the entire exercise is centred on assessment and 
grading of financial instrument. However, the importance of Credit Rating cannot be judged by the volume of business the Rating Agencies do but on the quality of Rating and its acceptance by the investors.

\section{Literature Review:-}

de Meijer, Carlo R. W.; Saaf, Michelle H. W.(2015) discussed about the credit crunch that is negatively impacting not only the financial markets, but also the global economy. Although this crisis can (justifiably) be blamed upon all parties involved (deal structures, banks, investors, etc.), a large part of the credit crisis has been blamed on the credit rating agencies (CRAs) that play a vital role in global securities and banking markets.

Frost, Carol Ann (2016) assessed the validity of widespread criticisms of the large, "nationally recognized" credit rating agencies (CRAs). This study evaluated important criticisms of the CRAs discussed in a recent Securities and Exchange Commission (SEC) staff report by using evidence from empirical research studies, and suggests many promising subjects for future research. Madegowda, J. (2017) argued that credit rating has made headway into the Indian capital market. The credit rating agencies have played a significant role in the Indian capital market as have their counterparts abroad since its inception.

\section{Objectives of the Study}

\section{To study the awareness level among investors regarding CRAs.}

\section{Hypothesis:-}

$\mathrm{H}_{01}$ : Age wise there is no significant difference in the awareness level of investors towards methodologies \& practices adopted by credit rating agencies for evaluation of long term financial instruments with respect to credibility and reliability.

$\mathrm{H}_{02}$ : Gender wise there is no significant difference in the awareness level of investors towards methodologies \& practices adopted by credit rating agencies for evaluation of long term financial instruments with respect to credibility and reliability.

\section{Research Design:-}

Sample Universe: Indore Division

Sampling Method: Purposive

Sample Size: 100 Investors

Tools for Data Collection: Self-Structured Questionnaire

Data Analysis: One Way ANOVA

\section{Results \& Discussions:-}

$\mathrm{H}_{01}$ : Age wise there is no significant difference in the awareness level of investors towards methodologies \& practices adopted by credit rating agencies for evaluation of financial instruments with respect to credibility and reliability.

Table 2: Age wise Mean and Standard Deviation

\begin{tabular}{|c|c|c|c|c|}
\hline Dimension & Age & N & Mean & Std. Deviation \\
\hline Credibility & Upto 30 years & 264 & 31.25 & 9.49 \\
\cline { 2 - 5 } & $31-40$ years & 126 & 34.65 & 7.75 \\
\cline { 2 - 5 } & $41-50$ years & 119 & 32.83 & 6.22 \\
\cline { 2 - 5 } & Above 50 years & 91 & 33.73 & 6.46 \\
\cline { 2 - 5 } & Total & 600 & 32.65 & 8.24 \\
\hline Reliability & Upto 30 years & 264 & 17.92 & 4.90 \\
\cline { 2 - 5 } & 31-40 years & 126 & 18.39 & 4.48 \\
\cline { 2 - 5 } & 41-50 years & 119 & 18.17 & 3.80 \\
\cline { 2 - 5 } & Above 50 years & 91 & 18.97 & 3.73 \\
\cline { 2 - 5 } & Total & 600 & 18.23 & 4.45 \\
\hline
\end{tabular}

From the table on mean of age group, it is disclosed that for the factor of credibility, the mean score of 3140 years 34.65 is the highest and the lowest mean score of upto 30 years is 31.25 years. For the factor of reliability, the mean of above 50 years is 18.97 is highest and the lowest mean score of up to 30 years is
17.92. It is perceived that as age increases the level of awareness also increased. 
International Journal of Trend in Scientific Research and Development (IJTSRD) ISSN: 2456-6470

Table 3: Age wise Analysis of Variance

\begin{tabular}{|l|l|l|l|l|l|l|}
\hline Dimension & & $\begin{array}{l}\text { Sum } \\
\text { Squares }\end{array}$ & of & $\begin{array}{l}\text { Mean } \\
\text { Square }\end{array}$ & F & *Sig. \\
\hline \multirow{4}{*}{ Credibility } & Between Groups & 1130.333 & 3 & 376.778 & 5.675 & .001 \\
\cline { 2 - 7 } & Within Groups & 39566.940 & 596 & 66.387 & & \\
\cline { 2 - 7 } & Total & 40697.273 & 599 & & & \\
\hline \multirow{3}{*}{ Reliability } & Between Groups & 80.060 & 3 & 26.687 & 1.348 & .258 \\
\cline { 2 - 7 } & Within Groups & 11800.738 & 596 & 19.800 & & \\
\cline { 2 - 7 } & Total & 11880.798 & 599 & & & \\
\hline
\end{tabular}

For the factor of credibility age wise there was significant difference found. As $\mathrm{P}$ value came out .001 which is less than .05 , hence the null hypothesis age wise there is no significant difference in the awareness level of investors towards methodologies $\&$ practices adopted by credit rating agencies for evaluation of financial instruments with respect to credibility was rejected. For the factor of reliability age wise there was no significant difference found. As $\mathrm{P}$ value came out .258 which is more than .05 , hence the null hypothesis age wise there is no significant difference in the awareness level of investors towards methodologies \& practices adopted by credit rating agencies for evaluation of financial instruments with respect to reliability was accepted.

$\mathrm{H}_{02}$ : Gender wise there is no significant difference in the awareness level of investors towards methodologies \& practices adopted by credit rating agencies for evaluation of financial instruments with respect to credibility and reliability.

Table 4: Gender wise Mean and Standard Deviation

\begin{tabular}{|l|l|l|l|l|}
\hline Dimension & Gender & $\mathbf{N}$ & Mean & $\begin{array}{l}\text { Std. } \\
\text { Deviation }\end{array}$ \\
\hline \multirow{2}{*}{ Credibility } & Male & 456 & 32.58 & 8.80 \\
\cline { 2 - 5 } & Female & 144 & 32.89 & 6.16 \\
\hline Reliability & Male & 456 & 18.24 & 4.65 \\
\cline { 2 - 5 } & Female & 144 & 18.20 & 3.74 \\
\hline
\end{tabular}

From the table on mean, it is disclosed that for the factor of credibility, the mean score of male is 32.58 high than female and for the factor of reliability, the mean of male is 18.24 is again high than the mean score of female. It is perceived that male have more knowledge about the credit rating.

Table 5: Gender wise T-Test

\begin{tabular}{|l|l|l|l|}
\hline Dimensions & $\mathrm{t}$ & $\mathrm{df}$ & $*$ Sig. (2-tailed) \\
\hline Credibility & -.399 & 598 & .690 \\
\hline Reliability & -.094 & 598 & .926 \\
\hline
\end{tabular}

For the factor of credibility gender wise there was no significant difference found. As $\mathrm{P}$ value came out .690 which is more than .05, hence the null hypothesis gender wise there is no significant difference in the awareness level of investors towards methodologies \& practices adopted by credit rating agencies for evaluation of financial instruments with respect to credibility was accepted.

For the factor of reliability gender wise there was no significant difference found. As $\mathrm{P}$ value came out .926 which is more than .05 , hence the null hypothesis gender wise there is no significant difference in the awareness level of investors towards methodologies \& practices adopted by credit rating agencies for evaluation of financial instruments with respect to reliability was accepted.

\section{Conclusion:-}

In spite of all the findings and criticisms, Rating services undoubtedly play a significant role in the development of efficient market and protection of interest of investors if rating agencies conduct their activities in true spirit. The rating agencies should take utmost care in initial rating as well as in surveillance. The market regulator should keep always an attentive eye on the activities of Rating Agencies. Therefore, nurturing a credible Rating system in the light of increased complexities in the market is an unavoidable necessity of the time. The Researcher is confident that both the parties' viz., Rating Agencies and the Market Regulator (SEBI) possess the requisite qualities to incorporate the above suggestions in their functioning.

This purpose of this study is to analyse the investors' perception towards credit rating agencies which includes a thorough analysis of awareness on credit rating agencies, investors' attitude towards performance of credit rating agencies in terms of credibility and reliability. The findings of this study examined the rating agencies in understanding the 
investors' perception, to frame appropriate mechanism for avoidance of fluctuations in the ratings and adopt appropriate strategy to serve stakeholders in the capital market. The researchers made an attempt to analyse the consistency in rating grades and process and may guide the investors by giving clear ideas for their investment decision.

\section{Suggestions:-}

On the basis of the findings of present study some suggestions have been given for improvements in future study as follows:

1. Credit rating agencies do not give any full proof reliability of their assessment but provide only an indication about the relative capability of various instruments.

2. The only those ratings are made public are accepted by the issuer companies which are accepted by the rating agencies. But the study suggested to the credit rating agencies to publish those ratings which are not accepted by the given companies.

3. The credit rating agencies should lay more emphasis on quantitative factors apart from qualitative aspects for rating which may not be more reliable and accurate.

4. At least when investment grade instruments default accountability can be fixed on Rating Agencies. Hence, SEBI should encourage setting up of a few more Rating Agencies in India.

5. The competition among Rating Agencies increases the quality of Rating by avoiding oligopoly market as it exists today. However, it is suggested that the Rating Agencies should consider near market movements and indicate positive and negative outlook along with the grading based on fundamentals.

6. The Rating completely depends upon the credibility of Rating Agencies. Credibility is the only weapon for sustainability.

\section{References}

1) Arora, M. (2003), Credit Rating in India Institutions, Methods and Evaluation, New Century Publications, Delhi, pp. 4, 10.

2) de Meijer, Carlo R. W.; Saaf, Michelle H. W.(2015) The credit crunch and credit rating agencies: Are they really striving towards more transparency? Journal of Securities Law,
Regulation \& Compliance. Vol. 1 Issue 4, p 322336.

3) Frost, Carol Ann (2016) Credit Rating Agencies in Capital Markets: A Review of Research Evidence on Selected Criticisms of the Agencies. Journal of Accounting, Auditing \& Finance. Vol. 22 Issue 3, p 469

4) Jain, T.; and Sharma, R. (2008), Credit Rating Agencies in India: A Case of Authority without Responsibility, Working Paper Series, Supreme Court of India and National Law University, April.

5) Madegowda, J.(2017) Working of Credit Rating Agencies in India: An Analysis of Investors' Perception. Journal of Behavioral Finance. Vol. 7 Issue $1 / 2$, p 92.

6) Rao, K. V.; Naidu, M. M.; and Rao, C. H. R. (1996), - Credit Rating Agencies in Indiall, in G. S. Batra (ed.), Management of Financial Institutions and Markets, Deep \& Deep Publications Pvt. Ltd., New Delhi, pp. 360-368.

7) Singh, J. (1996), -Credit Rating: An Innovative Financial Servicel, in G. S. Batra (ed.), Management of Financial Institutions and Markets, Deep \& Deep Publications Pvt. Ltd., New Delhi, pp. 291-304.

8) Rao, K. V.; Naidu, M. M.; and Rao, C. H. R. (1996), - Credit Rating Agencies in Indiall, in G. S. Batra (ed.), Management of Financial Institutions and Markets, Deep \& Deep Publications Pvt. Ltd., New Delhi, pp. 360-368. 